\title{
Pathologic Splenic Rupture Related to Non-Hodgkin Lymphoma
}

\author{
Non-Hodgkin Lenfomaya Bağlı Gelişen Patolojik Dalak Rüptürü
}

\author{
Alper Sözütek', Aydın Hakan Küpeli', Burhan Şaban', Sezgin Topuz', Murat Özdemir', Rana Çitil² \\ 'Gastroenterology Surgery Clinic, Necip Fazıl City State Hospital, Kahramanmaraş, Turkey \\ 2Pathology Clinic, Necip Fazıl Şehir Devlet Hastanesi, Kahramanmaraş, Turkey
}

\section{ABSTRACT}

Introduction: Pathologic splenic rupture (PSR) is described as the spontaneous rupture of a histologically diseased spleen in the absence of trauma. Although it is a complication that often occurs related to infectious diseases, it may rarely be observed in hematologic malignancies. A limited number of case reports about PSR exist in the current literature, even though the spleen is commonly involved in hematologic diseases. Hence, there is a lack of data in the current literature in terms of the clinical symptoms, treatment, and outcomes of the disease. In this study, we aimed to contribute to current data by discussing clinical outcomes of a case with PSR related to spleen lymphoma.

Case Report: A 57-year-old woman with a 5-month history of colic left upper abdominal pain was referred to our clinic. In her imaging tests, a splenic mass with a measure of $6 \times 4 \mathrm{~cm}$ was detected. The patient underwent splenectomy due to PSR while preparing for elective surgery.

Conclusion: PSR should be considered a rare complication in hematologic malignancies. Early diagnosis and treatment are the major factors that determine prognosis. Splenectomy seems to be the most appropriate approach in the treatment of PSR, even though a conservative approach is suggested in some cases.

Keywords: Spontaneous splenic rupture, hematologic malignancy, non-Hodgkin lymphoma

Received: 14.02.2014 Accepted: 14.04.2014

\section{ÖZET}

Giriş: Patolojik dalak rüptürü (PDR), herhangi bir travma olmadan histolojik olarak hastalıklı bir dalak dokusunun spontan olarak rüptüre olması olarak tarif edilir. Sıklıkla enfeksiyöz nedenlere bağlı olarak karşılaşılan bir komplikasyon olmasına rağmen nadir de olsa hematolojik malignitelerde de gözlenebilmektedir. Hematolojik hastalıklarda dalak sık tutulan bir organ olmasına rağmen patolojik rüptür literatürde bugüne kadar sınırlı sayıda olgu sunumu ile yerini almaktadır. Bu nedenle hastalığın klinik bulguları, tedavi ve takip sonuçları hakkında literatürdeki veri eksikliği bulunmaktadır. Bu çalışma ile dalakta lenfoma nedeni ile PDR gelişen bir kadın hastamızın klinik sonuçlarını tartışarak mevcut verilere katkı sağlamayı amaçladık.

Olgu Sunumu: 57 yaşında kadın hasta 5 aydır kolik tarzında devam eden sol üst kadran ağrısı nedeni ile kliniğimize konsülte edildi. Görüntüleme yöntemlerinde, dalakta $6 \times 4 \mathrm{~cm}$ boyutlarında kitle saptandı. Hasta elektif cerrahiye hazırlanırken, ani olarak PDR gelişmesi sonucu splenektomi uygulandı.

Sonuç: PDR, hematolojik kanserlerde görülebilen nadir bir komplikasyondur. Erken tanı ve tedavi prognozu belirleyen en önemli faktördür. Konservatif yaklaşım bazı olgularda önerilen tedavi seçeneği olsa da PDR de en uygun tedavi yönteminin splenektomi olduğunu düşünmekteyiz.

Anahtar Kelimeler: Spontan dalak rüptürü, hematolojik kanser, Non-Hodgkin lenfoma

Geliş Tarihi: 14.02.2014 Kabul Tarihi: 14.04.2014

\section{Giriş}

Dalak rüptürü, acil tanı ve tedavi gerektiren hayatı tehdit edici klinik bir durumdur. Sıklıkla künt toraks ve/veya karın travmasını takiben gelişebilen bir durum olmakla birlikte nadiren spontan olarak da gözlenebilir. Orloff ve Peskin'in tanımladığı kriterlere göre spontan dalak rüptürü (SDR) iki sınıfa ayrılmaktadır (1). Herhangi bir travma olmadan, histolojik olarak normal bir dalak dokusunun rüptüre olması "gerçek", hastalıklı dokunun rüptüre olması ise "patolojik" olarak sınıflandırılmaktadır. Patolojik dalak rüptürü sıklıkla enfeksiyöz nedenlere bağlı olarak gelişmekle birlikte nadiren de olsa onkolojik ve/veya hematolojik hastalıklar sonucunda da 


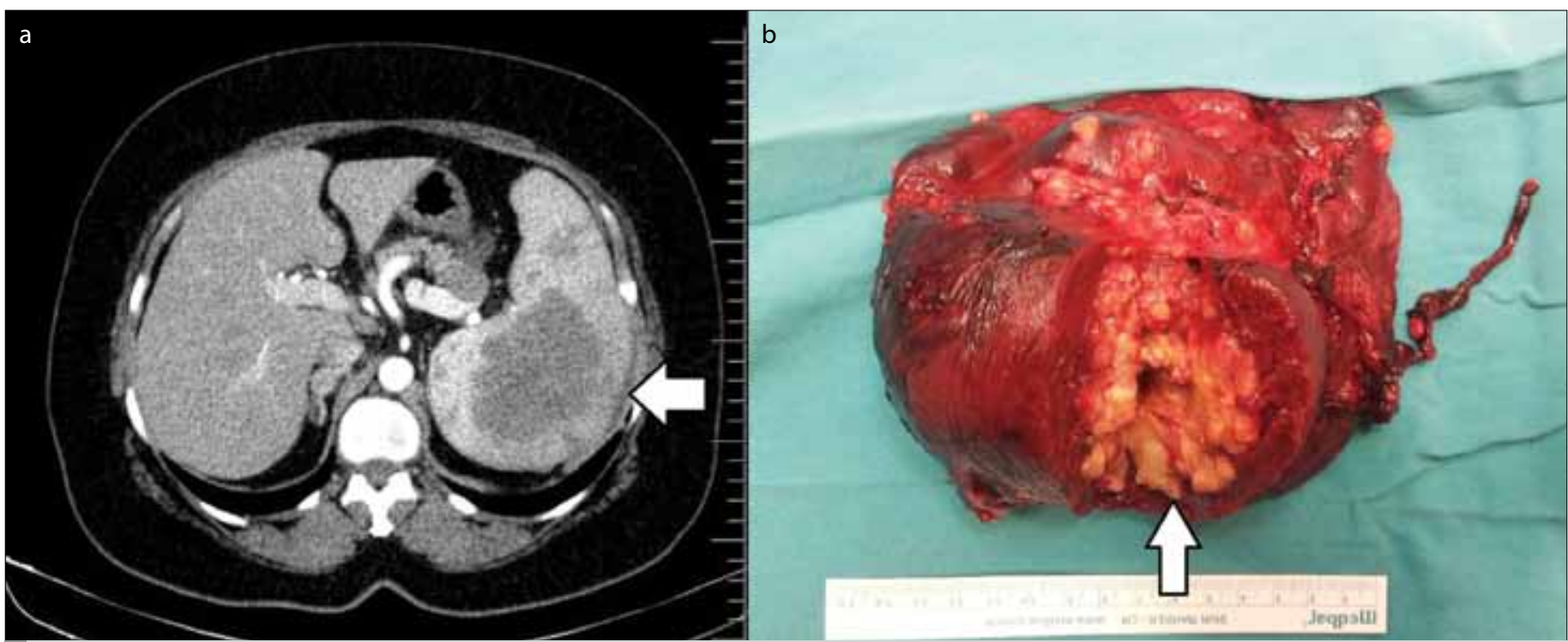

Şekil 1. Preoperatif dönemde dalakta lenfomanın BT görüntüsü (kitle ok ile işaretli) (a) Splenektomi materyali (posteriordan tümörün perfore olduğu alan ok ile işaretli) (b)

gözlenebilmektedir (2). Hematolojik malignitelere bağlı gelişen SDR, ilk defa 1966 yılında Knoblich (3) tarafından tanımlandıktan sonra günümüze kadar 136 olgu sunumu ile literatürde yerini almaktadır. Hasta sayısının az olması nedeni ile hastalığın klinik bulguları, tedavi ve takip sonuçları hakkında veri eksikliği dikkati çekmektedir. Bu olgu sunumu ile non-Hodgkin lenfomaya bağlı SDR gelişen bir hastamızın klinik sonuçlarını tartışarak literatürdeki verilere katkı sağlamak amaçlanmıştır.

\section{Olgu Sunumu}

57 yaşında kadın hasta, 5 aydır kolik tarzında devam eden sol üst kadran ağrısı nedeni ile kliniğimize başvurdu. Tıbbi öyküde herhangi bir özellik belirtmeyen hastanın fizik muayene ve laboratuar parametreleri normal olarak değerlendirildi. Tanıya yardım amaçlı istenen karın ultrasonografi (USG) de dalakta yaklaşık $6 \times 4 \mathrm{~cm}$ boyutlarında düzensiz sınırlı hemanjiom veya primer tümör ile uyumlu olabilecek solid bir kitleye rastlandı. Dalak boyutu 12x9 cm olarak belirtildi. Kitlenin kontrastlanma patternini net olarak değerlendirilebilmek amaçlı çekilen dinamik bilgisayarlı karın tomografi (BT) sonucu kitle Radyoloji uzmanı tarafından, sınırları düzgün olmaması ve periferik kontrastlanma göstermesi nedeni ile öncelikle primer dalak tümörü olarak değerlendirildi (Şekil 1a). Bu nedenle elektif şartlarda operasyona hazırlanan hasta 2 gün sonra ani başlayan şiddetli epigastrik ve sol üst kadran ağrısı nedeni ile acil servisimize başvurdu. Kan basıncı 90/50 mm-Hg, nabız 118/dk olarak ölçülen hasta soluk görünümlü idi. Karın muayenesinde özellikle üst kadranlarda olmak üzere yaygın defans ve rebound mevcuttu. Laboratuar bulgularında lökosit: 8200/mm³, Hb: 9,2 g/dL (2 gün önceki Hb: 12,4 g/dL), Plt: 230000/mm³ olarak saptandı. Biyokimya parametreleri normaldi. Direkt grafide özellik yoktu. Herhangi bir travma öyküsü tarif etmeyen hastada dalaktaki kitlenin spontan rüptüre olabileceği düşünülerek acil USG yapıldı. USG'de dalak boyutu $18 \times 9 \mathrm{~cm}$ olarak ölçüldü. Bununla birlikte, yaygın karın içi sıvı saptanması üzerine yapılan ponksiyonda kan aspire edildi. Hipovolemik şokta olan hasta sıvı replasmanını takiben onamı alınarak acil operasyona alındı. Orta hat kesi ile yapılan eksplorasyonda, karın içinden yaklaşık 700 cc hemorajik mayi aspire edildi. Aspirasyonu takiben dalak hilusuna yakın posterior yerleşimli yaklaşık $8 \times 6 \mathrm{~cm}$ boyutlarında solid kitlenin rüptüre olduğu ve aktif kanamanın olduğu tespit edildi (Şekil 1b). Karın içinde başka bir patolojik bulguya rastlanmadı. Splenektomi sonrası kanama kontrol altına alındı. Operasyon sonrası 16. saatte profilaktik amaçlı uygun antimikrobiyal profilaktikaşılar (depo penisilin, acti-Hib ${ }^{\circledR}$, Pnömo $23^{\circledR}$ ) tek doz hastaya uygulandı. Postoperatif dönemde herhangi bir cerrahi komplikasyon gelişmeyen hasta 7. günde sorunsuz taburcu edildi.

Histopatolojik incelemede, dalakta diffüz büyük B hücreli NonHodgkin lenfoma ile uyumlu olduğu gözlenen kısmi santral nekroz ile birlikte CD-20 ve LCA ile kuvvetli boyanan yaygın lenfoblastik hücre infiltrasyonu olduğu saptandı (Şekil 2). Diğer immunohistokimyasal çalışmalar, CD 15 (-), CD 8 (+), CD 30 (-) olarak rapor edildi.

\section{Tartışma}

Spontan dalak rüptürü, erken tanı ve tedavi gerektiren hayatı tehdit edici bir komplikasyondur. Oldukça nadir karşılaşılan bir klinik durum olması nedeni ile insidans tam olarak bilinmemektedir (4). Her ne kadar görülme sıklığı erkeklerde üç kat fazla olarak bildirilse de olgumuzun bayan olması dikkat çeken noktalardan biridir (5).

Patolojik dalak rüptürüne (PDR) neden olan birçok risk faktörü öne sürülmüş olmasına rağmen bunlardan en sık rastlanan enfeksiyöz (enfeksiyöz mononükleozis, malarya, riketsia) ve hematolojikonkolojik hastalıklardır. Polikistik hastalık, antikoagülan tedavi, akut pankreatit, portal hipertansiyon, hemanjiom, hamilelik ve amiloidoz PDR'e neden olan diğer nadir etyolojikfaktörlerdir (2-9). Immunolojik bir organ olması nedeni ile dalak, hematolojik malignensilerde ilk 


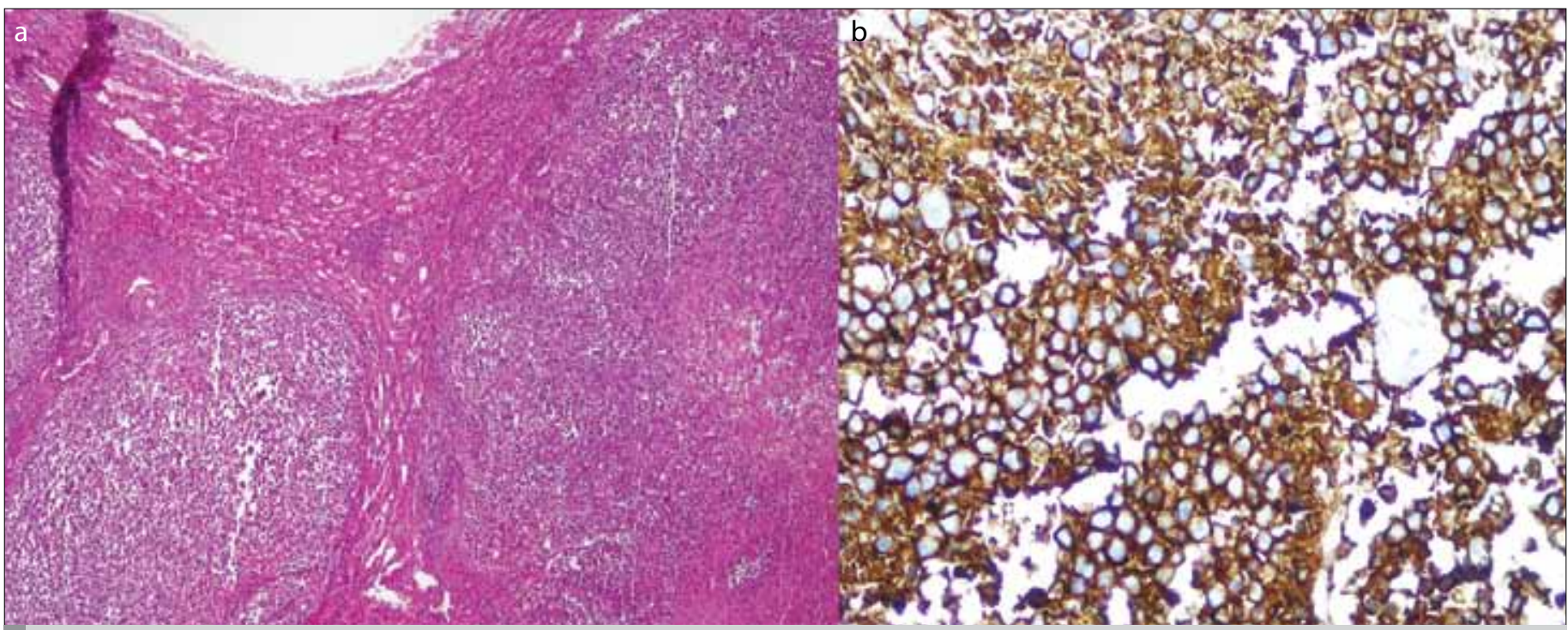

Şekil 2. Kitlenin histopatolojik görüntüsü. Çevre dalak dokusundan düzgün sınırla ayrılan tümöral alanın görüntüsü (H\&EX40) (a) Tümör hücrelerinde diffüz kuvvetli CD-20 pozitifliği görülmektedir (CD-20X200) (b)

tutulan organlardan biridir. Her ne kadar, günümüzde hematolojik malignensi insidansındaki artışa paralel olarak PDR sık karşılaşmayı beklediğimiz bir komplikasyon olsa da bugüne kadar sadece 136 olgu sunumu ile literatürde yerini alması ilginç bir durumdur. 1861-1999 yılları arasında Giagounidis ve ark. (5) tarafından bugüne kadar yapılan en geniş serili çalışmada olgumuzda olduğu gibi Non-Hodgkin lenfoma (\%34) ve akut myeloid lösemi (34\%) en sık etyolojik neden olarak göze çarpmaktadır. Kronik myeloid lösemi (\%18) ve lenfoblastik akut lösemi diğer nadir nedenler olarak bildirilmektedir.

Ileri yaş, erkek cinsiyet ve splenomegali en sık dalak rüptürüne neden olan faktörler olarak bildirilmektedir $(5,7)$. Özellikle splenomegali, rüptüre neden olan asıl faktör olarak suçlanmaktadır (6). Günlük klinik pratikte birçok ciddi splenomegalili hasta ile karşılaştığımız gözönüne alınırsa dalağın mevcut boyutunun değil de dalağın boyutlarındaki aniartışların rüptüre neden olabileceği düşüncesindeyiz. Hematolojik nedenlere bağlı gelişen PDR'nin etyopatogenezinde lenfoblastik infiltrasyona bağlı kapsül distansiyonu, dalak infarktı, intrasplenik ve/ veya subkapsüler hemorajiye neden olan koagülasyon bozuklukları, trombositopeni en sık suçlanan faktörlerdir $(2,6)$. Çıkardığımız spesmenin histopatolojik incelemesinde de dalakta santral doku nekrozu ile birlikte yoğun lenfoblastik hücre infiltrasyonu saptanmıştır. Tıbbi öyküde herhangi bir özellik belirtmeyen olgumuz da patolojik inceleme göz önüne alındığında, rüptürün muhtemel olarak aşırı lenfoblastik hücre infiltrasyonuna bağlı gelişen ani dalak distansiyonu sonucu geliştiğini düşündürmektedir. Koagülasyon bozuklukları ve trombositopeni suçlanan faktörler arasında olsa da hastamızın laboratuar değerlerinde herhangi bir patolojiye rastlanmamıştır (10).

Patolojik dalak rüptürünün erken tanısı hastanın prognozunu belirleyen en önemli faktördür. Hastanın öyküsü, fizik muayene ve USG, BT gibi yardımcı görüntüleme yöntemleri tanı için yeterli olmaktadır. Travma öyküsü olmadan ani başlangıçlı mide, sol üst kadran ve sol omuz ağrısı (Kehr belirtisi) tarif edilen en sık klinik yakınmadır $(6,7)$. Ek olarak, hastada koagülasyon faktörlerinde bozukluk olmadan derin bir anemi ve hipovolemik şok bulgularının saptanması kliniğin şiddetini gösteren önemli faktörlerdir. USG ve BT tanıyı desteklemek amaçlı kullanılan yöntemlerdir. BT'nin yapılamadığı veya zamanın önemli olduğu durumlarda tanı için olgumuzda uyguladığımız gibi USG eşliğinde karından SIVı aspirasyonu başvurulabilecek yöntemlerdendir (2).

Dalak rüptürü tespit edilir edilmez yüksek mortalite nedeni ile uygun tedavi en kısa sürede planlanmalıdır. Hastanın klinik durumuna göre konservatif veya cerrahi girişim tedavi seçenekleri arasındadır. Her ne kadar, hemodinamisi ve vital bulguları stabil olan hastalarda iyi monitorizasyon ve uygun resüsitasyonu takiben kanamanın kontrol altına alınabileceği bildirilmekte ise de Giagounidis ve ark'ın konservatif tedavi uyguladığı 43 hastanın 40'ı kaybedilmiştir $(5,11)$. Bununla birlikte, ülkemiz hukuksal şartları göz önüne alındığında konservatif tedavinin ne derece doğru olacağı ve zaten hastalıklı olan bir organın yerinde bırakılmasının hastaya ne kadar fayda sağlayacağı tartışma konusudur. Bu nedenle, her ne kadar hematolojik hastalığı bulunanlarda kanama ve enfeksiyon riski açısından morbiditesi ve mortalitesi yüksek bir operasyon olsa da splenektominin PDR'de en uygun tedavi seçeneği olduğu kanaatini taşımaktayız.

Postoperatif dönemde gözden kaçırılmaması gereken en önemli nokta, splenektomi sonrası gelişebilecek enfeksiyonlara karşı uygun profilaksinin mutlaka sağlanmasıdır (6). Profilaktik ajanın (depo penisilin, aşılar), ameliyat sonrası ilk 72 saat içinde uygulanması ve özellikle kapsüllü bakterilere karşı etkin olması önerilmektedir. 


\section{Sonuç}

PDR hematolojik bir malignitenin ilk belirtisi ve hayatı tehdit edici bir komplikasyon olarak karşımıza çıkabilmektedir. Erken tanı ve mümkün olan en kısa sürede splenektomi uygulanması prognozu belirleyen en önemli faktördür.

Informed Consent: Written informed consent was obtained from patient who participated in this case.

Peer-review: Externally peer-reviewed.

Author Contributions: Concept - A.S., A.H.K.; Design - A.S.; Supervision - B.S., R.C.; Materials - A.S., RC.; Data Collection and/or Processing - M.Ö., S.T., R.C.; Analysis and/or Interpretation - A.S., R.C.; Literature Review A.H.K., B.S., S.T., M.Ö.; Writer - A.S., A.H.K.; Critical Review - A.S.

Conflict of Interest: The authors declared no conflict of interest.

Financial Disclosure: The authors declared that this study has received no financial support.

Hasta Onamı: Yazılı hasta onamı bu olguya katılan hastadan alınmıştır.

Hakem Değerlendirmesi: Dış bağımsız.

Yazar Katkıları: Fikir - A.S., A.H.K.; Tasarım - A.S.; Denetleme - B.S., R.C.; Malzemeler - A.S., RC.; Veri toplanması ve/veya işlemesi - M.Ö., S.T., R.C.; Analiz ve/veya yorum - A.S., R.C.; Literatür taraması - A.H.K., B.S., S.T., M.Ö.; Yazıyı yazan - A.S., A.H.K.; Eleştirel Inceleme - A.S.

Çıkar Çatışması: Yazarlar çıkar çatışması bildirmemişlerdir.
Finansal Destek: Yazarlar bu çalışma için finansal destek almadıklarını beyan etmişlerdir.

\section{Kaynaklar}

1. Orloff M, Peskin GW. Spontaneous rupture of the normal spleen, a surgical enigma. Surg Gynecol Obstet 1958; 106: 1-11.

2. Biswas S, Keddington J, McClanathan J. Large B-cell lymphoma presenting as acute abdominal pain and spontaneous splenic rupture; a case report and review of relevant literature. World J Emerg Surg 2006; 1: 35. [CrossRef]

3. Knoblich R. Pathologic (so-called spontaneous) rupture in leukaemia and lymphoma. Mich Med 1966; 65: 105-10.

4. Szotkowski T, Szotkowska R, Pikalova Z, Tichy T, Flodr P, Tichy M, et al. Spontaneous splenic rupture in two patients with hematologic malignancy. Biomed Pap Med Fac Univ Palacky Olomouc Czech Repub 2007; 151: 113-6. [CrossRef]

5. Giagounidis AAN, Burk M,Meckenstock G, Koch AJ, Schneider W. Pathologic rupture of the spleen in hematologic malignancies: two additonal cases. Ann Hematol 1996; 73: 297-302. [CrossRef]

6. Chappuis J, Simoens C, Smets D, Duttmann R, Mendes da Costa P. Spontaneous rupture of the spleen in relation to a non-Hodgkin lymphoma. Acta Chir Belg 2007; 107: 446-8.

7. Gedik E, Girgin S, Aldemir M, Keles C, Tuncer MC, Aktas A. Non-traumatic splenic rupture: report of seven cases and review of the literature. World J Gastroenterol 2008; 14:6711-6. [CrossRef]

8. Oinonen R, Franssila K, Elonen E. Spontaneous splenic rupture in two patients with a blastoid variant of mantle cell lymphoma. Ann Hematol 1997; 74: 33-5. [CrossRef]

9. Tu AS, Tran MHT, Larsen CR. Spontaneous splenic rupture: report of five cases and a review of the literature. Emerg Radiol 1997; 4: 415-8. [CrossRef]

10. Bauer TW, Haskins GE, Armitage JO. Splenic rupture in patients with hematologic malignancies. Cancer 1981; 48: 2729-33. [CrossRef]

11. Smith JS Jr, Wengrovitz MA, DeLong BS. Prospective validation of criteria, including age, for safe, nonsurgical management of the ruptured spleen. J Trauma 1992; 33: 363-69. [CrossRef] 